Erratum

\title{
Erratum: Furtak, K., et al. Analysis of Soil Properties, Bacterial Community Composition, and Metabolic Diversity in Fluvisols of a Floodplain Area. Sustainability 2019, 11, 3929
}

\author{
Karolina Furtak ${ }^{1, * \mathbb{D}}$, Jarosław Grządziel ${ }^{1} \mathbb{( D}$, Anna Gałązka ${ }^{1}$ (D) and Jacek Niedźwiecki ${ }^{2}$ \\ 1 Department of Agricultural Microbiology, Institute of Soil Science and Plant Cultivation-State Research \\ Institute, Czartoryskich 8, 24-100 Puławy, Poland \\ 2 Department of Soil Science Erosion and Land Protection, Institute of Soil Science and Plant \\ Cultivation-State Research Institute, Czartoryskich 8, 24-100 Puławy, Poland \\ * Correspondence: kfurtak@iung.pulawy.pl; Tel.: +8-14786961
}

Received: 18 October 2019; Accepted: 21 October 2019; Published: 29 October 2019

The authors would like to make the following correction about the published paper [1]. The change is as follows:

Replacing the table:

Table 2. Formulae used to calculate indices based on Biolog microplates data.

\begin{tabular}{|c|c|c|}
\hline Index & Formula and Description & References \\
\hline $\begin{array}{c}\text { AWCD } \\
\text { (average well color } \\
\text { development) }\end{array}$ & $\begin{array}{l}\text { C-reading of the well OD590; } \\
\mathrm{R} \text {-reading of the control well OD590; } \\
n-\text { number of substrates on an EcoPlate }{ }^{\mathrm{TM}}(n=31) \text {. }\end{array}$ & [32] \\
\hline $\begin{array}{l}\text { Shannon diversity } \\
\qquad\left(\mathrm{H}^{\prime}\right)\end{array}$ & $\begin{array}{l}\qquad H^{\prime}=-\sum_{i=1}^{N} p_{i}\left(\ln p_{i}\right) \\
\mathrm{p}_{\mathrm{i}-\text { proportional color development of the well over the total colour }} \\
\text { development of all wells }(96) \text { of a plate; } \\
n-\text { number of substrates on an EcoPlate }\end{array}$ & [33] \\
\hline $\begin{array}{l}\text { Shannon evenness } \\
\text { (E) }\end{array}$ & $\begin{array}{l}E=H^{\prime} / \ln R \\
R \text {-substrate utilization richness (the number of wells with colour development) }\end{array}$ & [34] \\
\hline $\begin{array}{l}\text { Richness } \\
\text { (R) }\end{array}$ & $\begin{array}{l}\text { The number of wells with color development-number of utilised substrates } \\
\text { with OD590 } \geq 0.25\end{array}$ & [35] \\
\hline
\end{tabular}

with

Table 2. Formulae used to calculate indices based on Biolog microplates data.

\begin{tabular}{clc}
\hline Index & \multicolumn{1}{c}{ Formula and Description } & References \\
\hline $\begin{array}{c}\text { AWCD } \\
\text { (average well color } \\
\text { development) }\end{array}$ & $\begin{array}{l}\text { C-reading of the well OD590; } \\
\text { R-reading of the control well OD590; } \\
n \text {-number of substrates on an EcoPlate }\end{array}$ & [32] $(n=31)$. \\
\hline
\end{tabular}


Table 2. Cont.

\begin{tabular}{|c|c|c|}
\hline Index & Formula and Description & References \\
\hline $\begin{array}{l}\text { Shannon diversity } \\
\qquad\left(\mathrm{H}^{\prime}\right)\end{array}$ & $\begin{array}{l}\qquad H^{\prime}=-\sum_{i=1}^{N} p_{i}\left(\ln p_{i}\right) \\
\mathrm{p}_{\mathrm{i}-\text { proportional color development of the well over the total colour }} \\
\text { development of all wells (96) of a plate; } \\
n-\text { number of substrates on an EcoPlate }\end{array}$ & [33] \\
\hline $\begin{array}{l}\text { Shannon evenness } \\
\text { (E) }\end{array}$ & $\begin{array}{l}\qquad E=H^{\prime} / \ln R \\
R \text {-substrate utilization richness (the number of wells with colour development) }\end{array}$ & [34] \\
\hline $\begin{array}{l}\text { Richness } \\
\text { (R) }\end{array}$ & $\begin{array}{l}\text { The number of wells with color development-number of utilised substrates } \\
\text { with OD590 } \geq 0.25\end{array}$ & [35] \\
\hline
\end{tabular}

The authors and the Editorial Office would like to apologize for any inconvenience caused to the readers by these changes. The change does not affect the scientific results. The manuscript will be updated and the original will remain online on the article webpage.

\section{Reference}

1. Furtak, K.; Grządziel, J.; Gałąka, A.; Niedźwiecki, J. Analysis of Soil Properties, Bacterial Community Composition, and Metabolic Diversity in Fluvisols of a Floodplain Area. Sustainability 2019, 11, 3929. [CrossRef]

(C) 2019 by the authors. Licensee MDPI, Basel, Switzerland. This article is an open access article distributed under the terms and conditions of the Creative Commons Attribution (CC BY) license (http://creativecommons.org/licenses/by/4.0/). 